\title{
CHARACTERISTICS, CHEMICAL ANALYSIS AND BIOLOGICAL ACTIVITIES OF METHANOL EXTRACTS OF LICHENS PLEUROSTICTA ACETABULUM AND CLADONIA SUBULATA
}

Jovica Tomović1 ${ }^{*}$, Marijana Kosanić ${ }^{2}$, Branislav Ranković ${ }^{2}$, Perica Vasiljević ${ }^{3}$, Stevo Najman ${ }^{4}$ and Nedeljko Manojlović $^{*}$ ${ }^{1}$ University of Kragujevac, Faculty of Medical Sciences, Department of Pharmacy, Kragujevac, Serbia

${ }^{2}$ University of Kragujevac, Faculty of Science, Department of Biology, Kragujevac, Serbia ${ }^{3}$ University of Niš, Faculty of Science, Department of Biology, Niš, Serbia

${ }^{4}$ University of Niš, Serbia, Faculty of Medicine, Department of Biology and Human Genetics Niš, Serbia

\author{
ANTIOXIDANT ACTIVITY, CHEMICAL COMPOSITION, CYTOTOXIC \\ ACTIVITY, LICHEN; PHENOLS

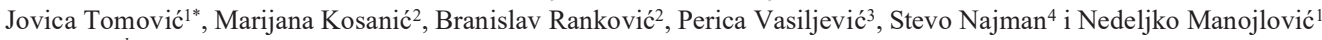 \\ ${ }^{1}$ Univerzitet u Kragujevcu, Fakultet medicinskih nauka, Katedra za farmaciju, Kragujevac, Srbija \\ ${ }^{2}$ Univerzitet u Kragujevcu, Prirodno-matematički fakultet, Katedra za biologiju, Kragujevac, Srbija \\ ${ }^{3}$ Univerzitet u Nišu, Prirodno-matematički fakultet, Katedra za biologiju, Niš, Srbija \\ ${ }^{4}$ Univerzitet u Nišu, Medicinski fakultet, Katedra za biologiju i humanu genetiku, Niš, Srbija
}

\begin{abstract}
The aim of this study is to investigate the chemical composition of methanol extracts of the lichens Pleurosticta acetabulum and Cladonia subulata and their antioxidant, and anticancer activities. The phytochemical analysis of the extracts of lichens was determined by HPLC-UV method. The predominant phenolic compounds in these extracts were norstictic acid and salazinic acids in $P$. acetabulum, while hypoprotocetraric acid and fumarprotocetraric acid were the major metabolites detected in C. subulata. Total phenolics and flavonoids in the extracts were determined spectrophotometrically, with the varied amount from 21.31 to $73.45 \mathrm{mg} \mathrm{GA} / \mathrm{g}$ and from 8.48 to $15.42 \mathrm{mg} \mathrm{RU/g}$, respectively. The lichen extracts showed comparable and strong antioxidant activity, exhibited higher DPPH and hydroxyl radical scavengings, inhibitory activity towards lipid peroxidation and reducing power. Cytotoxic effects of lichens were tested against HeLa S3 and LS174 cell lines using MTT method.The cytotoxic effects of $P$. acetabulum and C. subulata extracts toward two cancer cell lines were in the range from 39.17 to $>200 \mu \mathrm{g} / \mathrm{mL} I C_{50}$ value. The present study showed that the tested extracts of lichens demonstrated important antioxidant and anticancer effects. That suggests that these lichens can be used as new sources of the natural antioxidants and anti-cancer compounds.
\end{abstract}

Keywords: Antioxidant activity, Chemical composition, Cytotoxic activity, Lichen; Phenols.

\section{SAŽETAK}

Cilj ovog rada je ispitivanje hemijskog sastava, antioksidativne $i$ antitumorske aktivnosti metanolskih ekstrakata lišajeva Pleurosticta acetabulum i Cladonia subulata. Fitohemijska analiza ekstrakata lišajeva određena je HPLC-UV metodom. Dominantna fenolna jedinjenja u ovim ekstraktima bila su norstihninska kiselina $i$ salazinska kiselina $u$ vrsti P. acetabulum, dok su hipoprotocetrarinska kiselina i fumarprotocetrarinska kiselina glavni metaboliti otkriveni u C. subulata. Ukupni fenoli i flavonoidi u ekstraktima određeni su spektrofotometrijski, sa promenljivom količinom od 21,31 do 73,45 $\mathrm{mgG} / \mathrm{g}$ i od 8,48 do 15,42 mgRU/g. Ekstrakti lišajeva su pokazali snažnu antioksidativnu aktivnost, pokazali su veliku sposobnost neutralizacije DPPH i hidroksil radikala, inhibitornu aktivnost prema peroksidaciji lipida i redukcionu moć. Citotoksični efekti lišajeva testirani su na ćelijske linije HeLa S3 i LS174 koristeći MTT test. Citotoksični efekti ekstrakta P. acetabulum i C. subulata prema dve ćelijske linije karcinoma bili su u opsegu od 39,17 do > 200 $\mu \mathrm{g} / \mathrm{mL} I C_{50}$ vrednosti. Prikazana studija pokazala je da testirani ekstrakti lišaja poseduju važan antioksidativni i antikancerogeni efekat. To sugeriše da se ovi lišaji mogu koristiti kao novi izvori prirodnih antioksidanasa i antitumorskih agenasa.

Ključne reči: Antioksidativna aktivnost, Hemijski sastav, Citotoksična aktivnost, Lišajevi, Fenoli. 


\section{INTRODUCTION}

Lichens are complex symbiotic associations between fungi and algae which are important constituents of many ecosystems (1). Cladonia subulata was first described by G.H. Weber and F. H. Wigg. in 1780. This species is characterized by a squamulose thallus. C. subulata grows on bare soil over earth banks, rarely on wood, mainly in cool temperate regions. Pleurosticta acetabulum lichen was first described by J.A. Elix and H.T Lumbsch in 1988. P. acetabulum is characterized by a foliose, rosette-shaped thallus. This type of lichen belongs to thermophilic species of organisms and is found on the bark of deciduous trees in well-lit habitats. It can also be found on old tombstones and walls. Both lichen species are widespread on all continents (2-3).

To date, many lichens have proved to be a source of important secondary metabolites for pharmaceutical industries. Lichen extracts and lichen metabolites exhibit various biological activities such as antibiotic, antimycotic, antiviral, antiinflammatory, analgesic, antipyretic, antiproliferative and cytotoxic properties. Therefore, lichens are natural antibiotics and potential drugs (4-5). Lichens synthesize a variety of organic compounds as primary and secondary metabolites. These compounds exist within the thalli and typically form crystals on the surface of the fungal hyphae. And since these compounds are poorly soluble in water, they can usually be isolated from the lichens by organic solvents (6). It was found that secondary metabolites of lichens exhibit a strong antioxidant activity due to the fact that they consist of phenolic groups that have the ability to scavenge toxic free radicals (7). Depsides and depsidones are the largest classes of secondary metabolites of lichens. Depsides, tridepsides, and tetradepsides consist of two, three, and four hydroxybenzoic acid residues linked by ester groups, while molecules depsidones have an additional ether bond between the aromatic rings. Depsidones in lichen are believed to arise by oxidative cyclization of depsides. It has been found that depsidones are more efficient antioxidants than depsides (8-9). So far more than 1000 primary and secondary metabolites, including phenolic compounds, dibenzofurans, depsides, depsidones, depsones, lactones, quinones and pulvinic acid derivatives, characteristic of lichens have been identified and some of them are isolated (10).

The aim of the present study was to identify the secondary metabolites of Cladonia subulata and Pleurosticta acetabulum from Serbia using HPLC-UV analysis and to investigate in vitro antioxidant and anticancer activities of the methanol extract from these lichens. Also, the aim of the study is to compare the influence of solvents of different polarities on the extraction of individual components from the samples with our earlier studies (11-12).

\section{MATERIALS AND METHODS}

\section{Collection and identification of lichens sample}

Lichens were collected at the site of the eastern slope of the mountain Kopaonik on the territory of the Republic of Serbia during May 2013. The specimens of the types of lichen: Cladonia subulata and Pleurosticta acetabulum were determined at the Department of Biology and Ecology, the Faculty of Natural Sciences and Mathematics, the University of Kragujevac using the relevant key and monographs (13). The samples were deposited under the following voucher numbers: 1010 (Cladonia subulata) and 109 (Pleurosticta acetabulum). The demonstration samples are preserved in facilities of the Department of Pharmacy, the Faculty of Medical Sciences, Kragujevac. The specimen of each species has been retained in our laboratory for future reference.

\section{Preparation of the lichen extracts}

The dried material (thallus) of the selected types of lichens is crushed to a coarse powder (2-6 mm), using a mill. Thereafter, a separate extraction (4 hours) was performed with methanol using the Soxhlet apparatus. For the extraction, $100 \mathrm{~g}$ of the crushed thallus of the tested lichen species and $300 \mathrm{~mL}$ of methanol were used. After the extraction, the resulting liquid extracts were filtered through the filter paper (Whatman, No.1). Evaporation of the solvents used for the extraction was performed under the reduced pressure on the rotary vacuum evaporator (IKA). In this way, dry extracts were obtained, which were stored in dark glass bottles and used for further testing.

\section{High-performance liquid chromatography (HPLC) analysis}

HPLC with UV detection was used to expand and identify individual constituents of the extracts. The analyses were performed on the Agilent 1200 Series using the C18 column (ZORBAX Eclipse XDB-C18; $25 \mathrm{~cm} \times 4.6 \mathrm{~mm} ; 5 \mu \mathrm{m}$ ). Separate dot detection was performed using a Diode Array Detector (DAD) detector at 280, 330 and $350 \mathrm{~nm}$, and the absorption spectra of the components are recorded in the range of 200 to $400 \mathrm{~nm}$. Dissolved solubilized samples were filtered through using a pore size of $0.45 \mu \mathrm{m}$. Chromatographic separation was carried out using acetonitrile-water-phosphoric acid solvent system (90: 10: $0.1, \mathrm{v} / \mathrm{v} / \mathrm{v})$. The mobile phase flow rate was $1 \mathrm{~mL} / \mathrm{min}$. The column was thermostated at the temperature of $300{ }^{\circ} \mathrm{C}$. Identification of individual constituents of the extracts was made by comparing the retention times $\left(t_{R}\right)$ and UV spectra of constituents with standards $(\lambda$ $=200-400 \mathrm{~nm}$ ). Used standards were obtained from the following sources: hypoprotocetraric acid is isolated from Cladonia pyxidata, fumarprotocetraric acid is isolated from Hypogymnia physodes, salazinic acid isolated from the Lobaria pulmonaria, norstictic acid from the lichen Ramalina farinacea, protocetraric acid is isolated from Toninia Candida, and evernic acid is isolated from the lichen Evernia prunastri (11-12). 


\section{Determination of total phenolics}

Determination of total phenolics content was performed using the Folin-Ciocalteu method (14). The lichen extract was diluted to the concentration of $1 \mathrm{mg} / \mathrm{mL}$, and aliquots of $0.5 \mathrm{~mL}$ were mixed with $2.5 \mathrm{~mL}$ of Folin-Ciocalteu reagent (previously diluted 10-fold with distilled water) and $2 \mathrm{~mL}$ of $\mathrm{NaHCO}_{3}(7.5 \%)$. The resulting mixture was left for $15 \mathrm{~min}$ at the $45^{\circ} \mathrm{C}$, after which absorbance was measured at $765 \mathrm{~nm}$ on spectrophotometer against the blank sample. All spectrophotometric analyses were performed on a Cary 300 UV-VIS Spectrophotometer from Agilent Technologies. The content of the total phenolics was calculated using the equation obtained from a standard gallic acid calibration curve (y $=0.007 \mathrm{x}$ total polyphenols $[\mathrm{mg} \mathrm{GA} / \mathrm{g}$ of dry extracts $]+$ $0.483, \mathrm{R}^{2}=0.994$ ) and the results were expressed in $\mathrm{mg}$ equivalents of gallic acid per $\mathrm{g}$ of the dry extract (mg $\mathrm{GA} / \mathrm{g}$ ). The values are presented as means of triplicate analyses.

\section{Determination of total flavonoid content}

The content of total flavonoids in the extracts was determined by the Markham spectrophotometric method (15). The reaction mixture was prepared by mixing a certain volume of the extract $(2 \mathrm{~mL})$ of the concentration $1 \mathrm{mg} / \mathrm{mL}$ with $2 \mathrm{~mL}$ of $2 \%$ methanol solution of aluminum (III) chloride. The absorbance of the samples was measured at $415 \mathrm{~nm}$ on the spectrophotometer compared to the blank test. Methanol in the place of extract was used as the blank. The total flavonoid content was determined using the equation obtained from a standard rutin calibration curve $(\mathrm{y}=0.0296 \mathrm{x}$ total flavonoid [mg RU/g of dry extracts] $\left.+0.0204, \mathrm{R}^{2}=0.9992\right)$ and the results were expressed in mg equivalents of rutin per $g$ of the dry extract (mg RU/g). The values are presented as means of triplicate analyses.

\section{Antioxidant activity}

\section{Determination of total antioxidant capacity}

The total antioxidant activity of the lichen extracts was determined using the phosphomolybdenum method (16). This test is based on the reduction of Mo (VI)-Mo (V) by the antioxidant compounds and subsequent formation of a green phosphate/Mo (V) complex at acid pH. $0.3 \mathrm{~mL}$ of the sample extract was combined with $3 \mathrm{~mL}$ of the reagent solution $(0.6$ $\mathrm{M}$ sulfuric acid, $28 \mathrm{mM}$ sodium phosphate and $4 \mathrm{mM}$ ammonium molybdate). The tubes with the reaction solution were incubated at $95{ }^{\circ} \mathrm{C}$ for $90 \mathrm{~min}$. After that, the absorbance of the solution was measured at $695 \mathrm{~nm}$ using spectrophotometer versus the blank after cooling to room temperature. Methanol in the place of extract was used as the blank. Ascorbic acid (AA) was used as the standard. The total antioxidant capacity was determined as milligrams of ascorbic acid per gram of the dry extract (mg AA/g extract).

\section{Determination of DPPH free radical scavenging activity}

The free radical scavenging activity of the extracts was measured using the stable radical DPPH (1,1-diphenyl-2-picryl-hydrazil) according to the modification method from $\mathrm{Ku}$ marasamy (17). $8 \mathrm{mg}$ DPPH was dissolved in $100 \mathrm{~mL}$ methanol to obtain the concentration of $80 \mu \mathrm{g} / \mathrm{mL}$. Then, serial dilutions were carried out with the stock solution $(1 \mathrm{mg} / \mathrm{mL})$ of the extract. The resulting solutions $(2 \mathrm{~mL}$ each $)$ were mixed with DPPH $(2 \mathrm{~mL})$ and allowed to stand for $30 \mathrm{~min}$ for any reaction to occur, and the absorbance was measured at 517 nm. Ascorbic acid (AA) and butylated hydroxytoluene (BHT) dissolved in methanol were used as reference standards to make the stock solution with the same concentration $(1 \mathrm{mg} / \mathrm{mL})$. The control sample was prepared containing the same volume without the test compounds or reference antioxidants. Methanol 95\% was used as the blank. The inhibition DPPH free radical scavenging activity (\%) of the lichen extract was calculated using the following equation:

The inhibition capacity of DPPH radical $(\%)=$ Ac-As / Ac $\times 100$,

where the Ac-absorbance of the control solution (negative control), As is the absorbance of the sample solution or standard. The $\mathrm{IC}_{50}$ value $(\mu \mathrm{g} / \mathrm{mL})$, defined as the concentration of extract needed to reduce the DPPH concentration of the radical by $50 \%$, was obtained from the linear regression equation.

\section{Determination of hydroxyl radical scavenging activity}

In order to determine the ability of extracts to neutralize generated $\mathrm{OH}$ radical, the method described by Smirnoff \& Cumbes with certain modifications was applied (18). The reaction mixture $(3 \mathrm{~mL})$ contains $1.0 \mathrm{~mL}$ of $1.5 \mathrm{mM} \mathrm{FeSO} 4$, $0.7 \mathrm{~mL}$ of $6 \mathrm{mM}$ hydrogen peroxide, $0.3 \mathrm{~mL}$ of $20 \mathrm{mM}$ and 1 $\mathrm{mL}$ of the sample solution. The absorbance was measured at $562 \mathrm{~nm}$. Ascorbic acid and BHT were used as reference standards. The percentage of inhibition is calculated according to the equation: 100 ,

The inhibition capacity of $\mathrm{OH}$ radicals $(\%)=\mathrm{Ac}-\mathrm{As} / \mathrm{Ac} \times$

where the Ac-absorbance of the control solution (negative control), As is the absorbance of the sample solution or standard. The $\mathrm{IC}_{50}$ value $(\mu \mathrm{g} / \mathrm{mL})$, defined as the concentration of extract needed to reduce the $\mathrm{OH}$ concentration of the radical by $50 \%$, was obtained from the linear regression equation.

\section{Determination of inhibition of lipid peroxidation}

The antioxidant activity was determined by the thiocyanate method (19). The reaction mixture is made with $0.2 \mathrm{~mL}$ of extract samples (serial dilution from 1000 to 16.125 $\mu \mathrm{g} / \mathrm{mL}), 0.2 \mathrm{~mL}$ linoleic emulsion $(25 \mathrm{mg} / \mathrm{mL}$ in $99 \%$ ethanol) and $0.4 \mathrm{~mL}$ phosphate puffer $(50 \mathrm{mM}, \mathrm{pH}=7.4)$. The mixture is then incubated in the dark for $72 \mathrm{~h}$ at the temperature of $40^{\circ} \mathrm{C}$. An aliquot of the reaction mixture of $0.1 \mathrm{~mL}$ is 
taken and $3 \mathrm{~mL}$ of ethanol $(70 \%)$ and $0.1 \mathrm{~mL}$ of ammonium thiocyanate $(30 \%)$ are added. Exactly 3 minutes after adding $0.1 \mathrm{~mL}$ of iron III chlorides $(20 \mathrm{mM}$ in $3.5 \%$ hydrochloric acid), the absorbance of the red-colored mixture is measured at $500 \mathrm{~nm}$. Ascorbic acid and BHT were used as reference standards. The percentage of inhibition of lipid peroxidation is calculated according to the equation: 100 ,

The inhibition of lipid peroxidation $(\%)=\mathrm{Ac}-\mathrm{As} / \mathrm{Ac} \times$

where the Ac-absorbance of the control solution (negative control), As is the absorbance of the sample solution or standard. The $\mathrm{IC}_{50}$ value $(\mu \mathrm{g} / \mathrm{mL})$, defined as the concentration of the extract that inhibits lipid peroxidation for $50 \%$, was obtained from the linear regression equation.

\section{Reduction capacity}

The reducing capacity or reducing power was first described by Oyaizu (20). One milliliter of samples was mixed with $2.5 \mathrm{~mL}$ phosphate buffer $(0.2 \mathrm{M}, \mathrm{pH} 6.6)$ and $2.5 \mathrm{~mL}$ potassium ferricyanide (1\%). Then $2.5 \mathrm{~mL}$ of trichloroacetic acid was added to the mixture and the mixture was spinning at $3000 \mathrm{rpm}$ for 10 minutes. Take $2.5 \mathrm{~mL}$ of the upper layer (supernatant), add $2.5 \mathrm{~mL}$ of distilled water and $0.5 \mathrm{~mL}$ of iron three chlorides. The absorbance of the solution was measured at $700 \mathrm{~nm}$ on the spectrophotometer compared to the blank test. Ascorbic acid was used as a positive control. An increase in the absorption of the solution shows how much reducing power is increased.

\section{Cytotoxic activity}

\section{Cell line}

The human cervix adenocarcinoma HeLa S3 cells (ATCC CCL-2.2) and human colon adenocarcinoma LS174 cells (ATCC CL-188) were purchased from the American Type Culture Collection (Manassas, VA, United States). The cell line was cultured in a nutrient medium RPMI-1640, (pH 7.2) with thermally inactivated $\left(56{ }^{\circ} \mathrm{C}, 30 \mathrm{~min}\right.$.) fetal bovine serum $(10 \mathrm{~mL} / 100 \mathrm{~mL}), \mathrm{L}$-glutamine $(3 \mathrm{mmol} / \mathrm{L})$, streptomycin (100 mg/mL), penicillin (100 lU/mL), and HEPES (25 mM). The cell cultures were cultured in an incubator in the atmosphere saturated with water vapor, in the presence of $5 \% \mathrm{CO} 2$, at the temperature of $37{ }^{\circ} \mathrm{C}$.

\section{Experimental design}

The tested solution of extracts was made in DMSO (stock concentration $=100 \mathrm{mg} / \mathrm{mL}$ ). The applied diluted solutions were the concentrations $200,75,25,10 \mu \mathrm{g} / \mathrm{mL}$. Cells for the cytotoxic activity (20000 cells/well) and antiproliferative activity (5000 cells/well) in $100 \mu \mathrm{L}$ of a nutrient medium were seeded in 96-sterile plates and incubated for 24 hours under the atmosphere of saturated aqueous vapor at $37{ }^{\circ} \mathrm{C}$ and with $5 \% \mathrm{CO} 2$. The cells were incubated with the test extracts of lichen, as well as the controls for the next 24 hours for the cytotoxic activity and $72 \mathrm{~h}$ for the antiproliferative activity, followed by MTT test. As a negative control, the cells that grow only in the culture medium are used, while positive controls were cis-DDP (cis-diammindihloroplatinum).

\section{MTT test}

The MTT standard in vitro test for viability and cell proliferation (21) was used. After the incubation of the cells with the extracts, the cells were washed with $100 \mu \mathrm{l}$ of PBS (phosphate buffer solution) and MTT $(20 \mu \mathrm{L})$ was added. The MTT reduction (absorption) measurement was performed spectrophotometrically at the wavelength of $540 \mathrm{~nm}$ on a multichannel spectrophotometer (Multiskan Ascent No354, Thermo Labsystems, Finland). The results are presented as the intensity of MTT reduction relative to the negative control. The absorbance of the control was taken $100 \%$ and in relation to it, the percentage values of the extracts were calculated relative to the control according to the formula:

$\%$ viability $/$ proliferation of extracts $=$ absorbance values of treated cells with extract or positive control / negative absorbance value $\mathrm{X} 100$

The antitumor activity is expressed as the $\mathrm{IC}_{50}$ value. The $\mathrm{IC}_{50}$ value is defined as a concentration that inhibits cell survival by $50 \%$ or inhibits cell growth. The results are presented as the arithmetic mean of the tetraplicates for each concentration of the standard deviation.

\section{Statistical analysis}

All measurements are repeated three times, and the results are displayed as the mean \pm standard error (mean $\pm \mathrm{SD}$ ). The statistical analyses were performed using Microsoft Excel and SPSS software package, version 20 (IBM SPSS Statistics 20 Inc. Chicago, Illinois 60606-6307 U.S.A.). One-way ANOVA was used to determine differences between the mean measurement values, with statistical significance of $p$ $<0.05$.

\section{RESULTS}

The HPLC chromatogram for standards and the methanol extracts of the species $C$. subulata and $P$. acetabulum recorded at $254 \mathrm{~nm}$ are represented in Figures 1 and 2. The results of the HPLC analysis of the methanol extract of the Pleurosticta acetabulum indicate presence of four metabolites: salazinic acid (at the retention time $t_{R}=1.56 \pm 0.20$ ), norstictic acid $\left(t_{R}=2.70 \pm 0.10\right)$, protocetraric acid $\left(t_{R}=3.24 \pm 0.20\right)$ and evernic acid $\left(t_{R}=5.08 \pm 0.10\right)$. The dominant peak in the chromatograms originates from depsidone compound, norstictic acid. The UV spectrum of norstictic acid has $3 \mathrm{ab}-$ sorption maxima $(212,239,320 \mathrm{~nm})$. Besides these signals in HPLC chromatogram of the methanol extract of $P$. acetabulum, medium to low-intensity signals were identified, originating from: salazinic acid, protocetraric acid and evernic acid. The results of the HPLC analysis of the methanol extracts of the Cladonia subulata indicate the presence of two metabolites: hypoprotocetraric acid $\left(t_{R}=3.10 \pm 0.20 \mathrm{~min}\right)$ and fumaroprotocetraric acid $\left(t_{R}=4.14 \pm 0.10 \mathrm{~min}\right)$. The 
dominant peak in the chromatograms originates from depsidone compound, fumaroprotocetraric acid. The UV spectrum of fumaroprotocetraric acid has 3 absorption maxima $(212,240,318 \mathrm{~nm})$. Besides fumaroprotocetraric acid, the tested extracts contain depsidone hypoprotocetraric acid, whose signal intensity was significantly smaller than the peak from fumaroprotocetraric acid.

Figure 1. HPLC chromatogram of mixed standards used for identification of the lichen compounds at $254 \mathrm{~nm}$

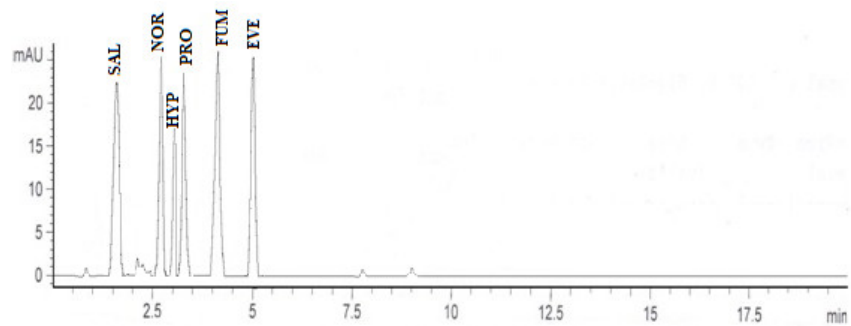

(SAL-Salazinic acid; NOR-Norstictic acid; HYP-Hypoprotocetraric acid; PRO-Protocetraric acid; FUM- Fumarprotocetraric acid; EVE- Evernic acid)
Figure 2. HPLC chromatograms of the methanol extracts of $\mathrm{P}$. acetabulum and C. subulata at $254 \mathrm{~nm}$.

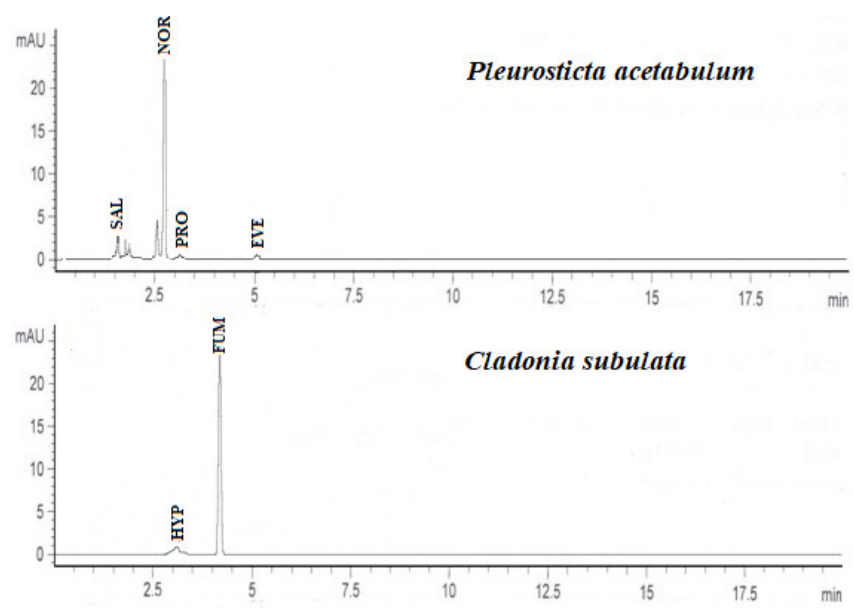

(SAL-Salazinic acid; NOR-Norstictic acid; HYP-Hypoprotocetraric acid; PRO-Protocetraric acid; FUM- Fumarprotocetraric acid; EVE- Evernic acid)

Table 1. Retention time of the examined lichen substances and their absorbance maxima (nm).

\begin{tabular}{|c|c|c|c|c|}
\hline Lichen & Compound & Class substances & $\begin{array}{l}\text { Retention time } \\
\left(t_{\mathrm{R}} \pm \mathrm{SD}\right)^{*}(\mathrm{~min})\end{array}$ & $\begin{array}{l}\text { Absorbance max- } \\
\text { ima (nm) }\end{array}$ \\
\hline \multirow{4}{*}{$\begin{array}{l}\text { Pleurosticta acetab- } \\
\text { ulum }\end{array}$} & Salazinic acid & Depsidone & $1.56 \pm 0.20$ & $212,238,310$ \\
\hline & Norstictic acid & Depsidone & $2.70 \pm 0.10$ & $212,239,320$ \\
\hline & Protocetraric acid & Depsidone & $3.24 \pm 0.20$ & $212,242,320$ \\
\hline & Evernic acid & Depside & $5.08 \pm 0.10$ & $213,270,305$ \\
\hline \multirow[t]{2}{*}{ Cladonia subulata } & $\begin{array}{l}\text { Hypoprotocetraric } \\
\text { acid }\end{array}$ & Depsidone & $3.10 \pm 0.20$ & $216,258,320$ \\
\hline & $\begin{array}{l}\text { Fumarprotocetraric } \\
\text { acid }\end{array}$ & Depsidone & $4.14 \pm 0.10$ & $212,240,318$ \\
\hline
\end{tabular}

The structures of the detected compounds are shown in Figure 3.

Figure 3. Chemicals structures of the identified compounds<smiles>Cc1cc(O)c(C=O)c2c1C(=O)Oc1c(CO)c(O)c3c(c1O2)C(O)OC3=O</smiles>

Salazinic acid<smiles>Cc1cc(O)c(C=O)c2c1C(=O)Oc1c(C)c(O)c3c(c1O2)C(O)OC3=O</smiles>

Norstictic acid<smiles>Cc1cc(O)c(C=O)c2c1C(=O)Oc1c(CO)c(O)c(C(=O)O)c(C)c1O2</smiles>

Protocetraric acid 


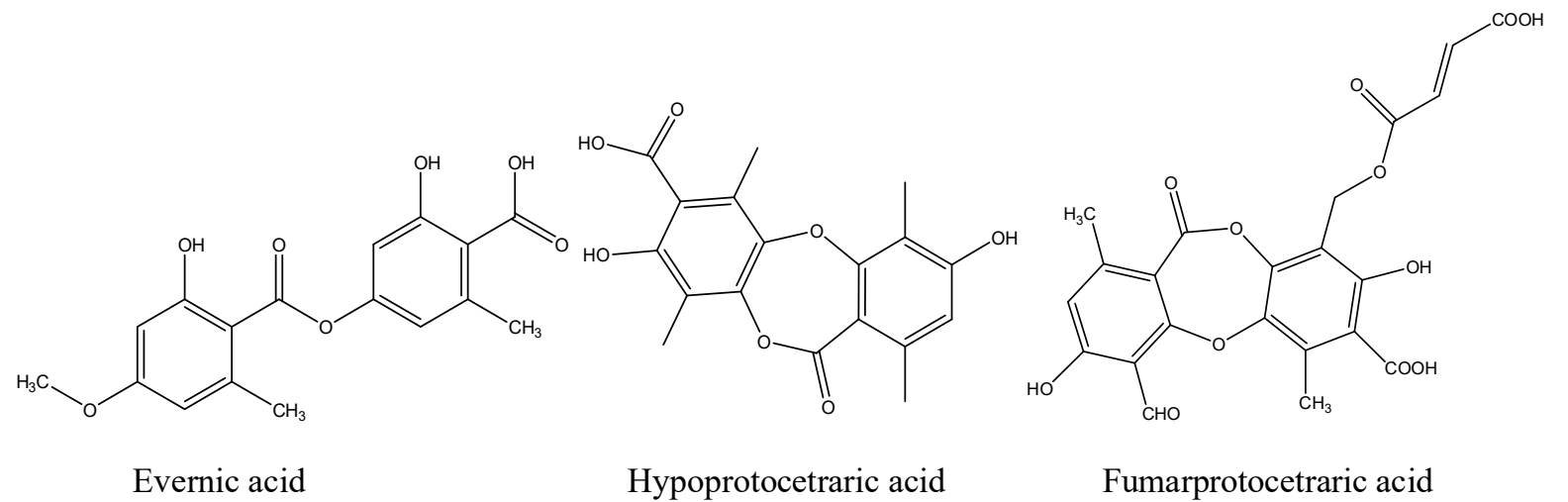

Table 2 shows the results of determination of total phenols, total flavonoids and the antioxidant capacity of the examined lichen extracts. The total phenolic contents expressed as gallic acid equivalents of the methanol extracts amounted to 73.45 mg GA/g for P. acetabulum and $21.31 \mathrm{mg} \mathrm{GA} / \mathrm{g}$ for $C$. subulata, respectively. The results for the total antioxidant capacity showed that the methanol extracts of $P$. acetabulum with the antioxidant capacity of $74.29 \mathrm{mg} \mathrm{AA} / \mathrm{g}$ possess a greater antioxidant activity than the methanol extract of $C$. subulata.

Table 2. Polyphenolic content (phenolic and flavonoids) and total antioxidant capacity of the methanol extracts of Cladonia subulata and Pleurosticta acetabulum

\begin{tabular}{llll}
\hline Lichen & $\begin{array}{l}\text { Phenolics content } \\
\text { (mg GA/g) }\end{array}$ & $\begin{array}{l}\text { Flavonoids con- } \\
\text { tent } \\
\text { (mg RU/g) }\end{array}$ & $\begin{array}{l}\text { Antioxidant ca- } \\
\text { pacity (mg } \\
\text { AA/g) }\end{array}$ \\
\hline P. acetabulum & $73.45 \pm 0.82$ & $15.42 \pm 0.55$ & $74.29 \pm 1.36$ \\
C. subulata & $21.31 \pm 1.19$ & $8.48 \pm 0.57$ & $25.36 \pm 0.94$ \\
\hline
\end{tabular}

*Values are expressed as mean $\pm \mathrm{SD}$ of triplicate measurements; GA - gallic acid equivalents; RU - rutin equivalents;

AA- ascorbic acid equivalents;

Table 3. Antioxidant activity of the examined C. subulata and P. acetabulum methanol extracts and control.

\begin{tabular}{|c|c|c|c|}
\hline \multirow[b]{2}{*}{ Lichen/control } & \multicolumn{3}{|l|}{$\mathrm{IC}_{50}(\mu \mathrm{g} / \mathrm{mL})$} \\
\hline & $\begin{array}{l}\text { DPPH scav- } \\
\text { enging activity }\end{array}$ & $\begin{array}{l}\text { OH radical } \\
\text { scavenging ac- } \\
\text { tivity }\end{array}$ & $\begin{array}{l}\text { Inhibition lipid } \\
\text { peroxidation }\end{array}$ \\
\hline P. acetabulum & $48.52 \pm 0.77$ & $163.83 \pm 0.95$ & $74.30 \pm 1.48$ \\
\hline C. subulata & $296.75 \pm 0.61$ & $595.35 \pm 7.78$ & $151.96 \pm 2,79$ \\
\hline $\begin{array}{l}\text { Ascorbic acid } \\
\text { BHT }\end{array}$ & $\begin{array}{l}6.05 \pm 0.34 \\
15.61 \pm 1.26\end{array}$ & $\begin{array}{l}150.55 \pm 2.31 \\
33.92 \pm 0.79\end{array}$ & $\begin{array}{l}>1000 \\
1.00 \pm 0.23\end{array}$ \\
\hline
\end{tabular}

*Values are expressed as mean $\pm \mathrm{SD}$ of triplicate measurements; AA- ascorbic acid equivalents; BHT- Butylhydroxytoluene

The assessment of the antioxidant activity showed that the tested extracts were able to scavenge DPPH radical (Table 3). The results of the hydroxyl radical scavenging activity of the tested extracts showed that the methanol extract of $P$. acetabulum had the highest activity $(163.83 \mu \mathrm{g} / \mathrm{mL})$, while the methanol extract of $C$. subulata showed the lowest activity $(595.35$ $\mu \mathrm{g} / \mathrm{mL}$ ). The results of the inhibitory activity towards lipid peroxidation (Table 3 ) demonstrated that all examined extracts of $P$ acetabulum and $C$. subulata exhibited a significant inhibitory activity. The $\mathrm{IC}_{50}$ value of the methanol extract was 74.30 $\mu \mathrm{g} / \mathrm{mL}$ and for C. subulata $151.96 \mu \mathrm{g} / \mathrm{mL}$. The results of the reducing power of the tested lichen extracts are shown in Table 4. Measured values of absorbances varied in the range from 0.011 to 0.25 . Higher absorbance indicates higher reducing power. The extract of $P$. acetabulum showed higher reducing power than $C$. subulata in all examined concentrations. 
Table 4. Reducing power of the methanol extracts of lichens Cladonia subulata and Pleurosticta acetabulum and ascorbic acid

\begin{tabular}{llllll}
\hline & \multicolumn{5}{c}{ Absorbance $(\mathbf{7 0 0} \mathbf{~ n m})$} \\
\cline { 2 - 6 } Lichen & $\mathbf{1 0 0 0} \boldsymbol{\mu g} / \mathbf{m L}$ & $\mathbf{5 0 0} \boldsymbol{\mu \mathbf { g }} / \mathbf{m L}$ & $\mathbf{2 5 0} \boldsymbol{\mu \mathbf { g }} / \mathbf{m L}$ & $\mathbf{1 2 5} \boldsymbol{\mu g} / \mathbf{m L}$ & $\mathbf{6 2 . 5} \boldsymbol{\mu \mathbf { g }} / \mathbf{m L}$ \\
\hline$P$. acetabulum & $0.25 \pm 0.011$ & $0.123 \pm 0.003$ & $0.063 \pm 0.003$ & $0.035 \pm 0.006$ & $0.018 \pm 0.002$ \\
C. subulata & $0.093 \pm 0.007$ & $0.045 \pm 0.003$ & $0.031 \pm 0.002$ & $0.026 \pm 0.005$ & $0.011 \pm 0.002$ \\
\hline Ascorbic acid & $2.113 \pm 0.032$ & $1.654 \pm 0.021$ & $0.0957 \pm 0.008$ & $0.0478 \pm 0.004$ & $0.0247 \pm 0.004$ \\
\hline \multicolumn{5}{c}{ *Values are expressed as mean \pm SD of triplicate measurements; }
\end{tabular}

Table 5. Cytotoxic activity of the extracts on the HeLa S3 and LS174 cells line (after $24 \mathrm{~h}$ and $72 \mathrm{~h}$ incubation)

\begin{tabular}{|c|c|c|c|c|}
\hline \multirow{3}{*}{ Lichen } & \multicolumn{4}{|c|}{$I C_{50}(\mu g / m L)$} \\
\hline & \multicolumn{2}{|c|}{ HeLa S3 } & \multicolumn{2}{|c|}{ LS174 } \\
\hline & $24 \mathrm{~h}$ & $72 \mathrm{~h}$ & $24 \mathrm{~h}$ & $72 \mathrm{~h}$ \\
\hline P. acetabulum & $64.30 \pm 2,89$ & $39.17 \pm 5.54$ & $66.09 \pm 1.61$ & $>200$ \\
\hline C. subulata & $>200$ & $>200$ & $>200$ & $>200$ \\
\hline$C i s-D D P$ & $2.16 \pm 0.67$ & $0.78 \pm 0.21$ & $5.89 \pm 0.92$ & $2.48 \pm 0.32$ \\
\hline
\end{tabular}

Table 5 shows the $\mathrm{IC}_{50}$ values of cytotoxic/cytostatic activity of the tested extracts on HeLa and LS174 cells, determined by the MTT assay. The highest cytotoxic/cytostatic activity was shown by the methanol extract of $P$. acetabulum against HeLa S3 cells $\left(\mathrm{IC}_{50}=64.30 \mu \mathrm{g} / \mathrm{mL}\right.$ after $24 \mathrm{~h}$ of incubation; $\mathrm{IC}_{50}=39.17 \mu \mathrm{g} / \mathrm{mL}$ after $72 \mathrm{~h}$ incubation) and LS174 $\left(\mathrm{IC}_{50}=66.09 \mu \mathrm{g} / \mathrm{mL}\right.$ ), while the methanol extract of $C$. subulata had no significant cytotoxic activity according to the cell lines either after $24 \mathrm{~h}$ or after $72 \mathrm{~h}$ of incubation.

\section{DISCUSSION}

The identification of secondary metabolites in the methanol extracts of $P$. acetabulum and $C$. subulata and their antioxidant and anticancer potentials were presented in this study. In the investigated extracts, depsidones and depsides were present as the most abundant substances classes. Comparing the methanol lichen extracts with our earlier study of the acetone extracts of $P$. acetabulum and C. subulata, the presence of the same metabolites was identified, but signal intensities and areas below the absorption maximum of certain secondary metabolites differed, which is consistent with the ability of the solvent (acetone and methanol) to dissolve more or less of these metabolites, by the principle of "dissolve similarly" (11-12). Such data indicate the influence of solvents of different polarity on the extraction of individual components from the samples (22).

The results for total phenolics and flavonoids content showed that the methanol extract of lichens had a higher total phenolic content than the acetone extract which we examined in our earlier research (11). Theobtained results that the methanol extracts contain the highest content of phenol and flavonoids are in accordance with the literature data where it has been shown that the phenol compounds are more soluble in the polar solvents (23).

Until now, many researchers have investigated the antioxidant properties of many lichens extracts and some of them showed a very good antioxidant activity (24-26). If we compare the same lichens species but different extraction solvent, the methanol extract had a greater antioxidant capacity than the acetone extract. There is a positive correlation between total phenols and the results of the antioxidative activity testing. These results agree with the literature (27-28). Based on the $\mathrm{IC}_{50}$ values, it is evident that the methanol extract of $P$. acetabulum exhibits the highest antiradical activity against DPPH $(48.52 \mu \mathrm{g} / \mathrm{mL})$ compared to the acetone extract of $P$. acetabulum and acetone and methanol extracts of $C$. subulata but still significantly less than commercially used butylhydroxytoluene and ascorbic acid (11-12). Also, the methanol extracts of $P$. acetabulum and C. subulata showed a stronger antioxidant activity than the extract of Toninia candida and Usnea barbata (29), and many other lichen species $(8,27)$. The results of the antioxidant activity ( $\mathrm{OH}$ radical scavenging activity, inhibition lipid peroxidation and reducing power) suggest that the methanol extracts of $P$. acetabulum and $C$. subulata were free radical scavengers, acting possibly as primary antioxidants. The tested extracts show a strong antioxidant activity against different oxidative systems. The strong antioxidant activity is the result of a high total phenolic content of the tested extracts (25). Phenolic compounds express the antioxidant effects mainly due to their redox properties, which can play an important role in absorbing and neutralizing free radicals, quenching singlet and triplet oxygen, or decomposing peroxides (30). Some metabolites of lichens in 
their structure contain phenolic groups which are considered to be a key element for the antioxidative efficiency (31). All identified secondary metabolites possess two phenolic groups in their molecules. Norstictic acid, evernic acid, salazinic acid, fumarprotocetraric acid and protocetraric acid, isolated from different lichen species are relatively strong antioxidant agents $(8,32-34)$. Nevertheless, it should be taken into consideration that individual phenolics may have distinct antioxidant activities, there may be antagonistic or synergistic interactions between phenolics and other compounds (35).

The methanol extracts of lichens showed a weaker cytotoxic effect according to the tested cell lines compared to the acetone extracts in our previous studies (11-12). There are previous reports on examination of the cytotoxic activity of many lichens (36-37), but in this study, the cytotoxic activity of the methanol extracts of $P$. acetabulum and $C$. subulata was explored for the first time. Relatively few lichen substances have been screened in detail for a biological activity and therapeutic potential, principally due to difficulties in obtaining them in quantities and purities sufficient for structural elucidation and pharmacological testing (38). So far, a limited number of studies have been published where the mechanism of action against cancer cell lines was explored (39). The molecular mechanism of cell death by the lichen compounds includes cell cycle arrest, apoptosis, necrosis, and inhibition of angiogenesis (40). There are several studies about the antitumor activity of depsides and depsidones including some of the identified lichen metabolites in the examined extracts $(8,32-34)$. Generally, depsidones showed a stronger cytotoxic activity than depsides. The strong biological activity of some depsidones may be due to the strong hydrogen bond between the aldehyde group at C3 and the hydroxyl group at $\mathrm{C} 4$. Depsidones, salazinic acid, norstictic acid, and fumarprotocetraric acid, were evaluated for their cytotoxic activity towards hepatocytes from a rat and lymphocytes from rat spleens (41-42). The research has shown that salazinic acid, stictic acid and fumarprotocetraric acid showed apoptosis of hepatocytes in a dose-dependent manner with stictic acid showing the strongest apoptotic activity. Also, in the work of Pejin and associates, it has been shown that the results suggest a moderate anticancer activity towards malignant HT-29 of stictic acid (43). This may indicate that norstictic acid can be considered as a promising lead compound for the design of novel human colon adenocarcinoma drugs.

\section{CONCLUSION}

This is the first research dealing with the chemical composition, antioxidant and cytotoxic activity of the methanol extracts of these lichens. The extracts of these lichens showed significant antioxidant and anticancer activities in vitro. The present study provides the data supporting the use of $P$. acetabulum and $C$. subulata extracts as natural antioxidant agents and confirms that these lichens represent a significant source of phenolic compounds. There is a need to continue to investigate the research in the field of phytochemistry and biological activity of lichens with particular reference to the compound of lichens that gives promising results. The attention should also be paid to identifying the specific mechanisms of action and extensive clinical studies to use promising drug therapies based on the lichens substances.

\section{ACKNOWLEDGMENTS}

This research was supported by the Ministry of Education and Science of Serbia, projects number: 172015 and 173032.

\section{REFERENCES}

1. Verma N, Behera BC, Sonone A, Makhija U. Lipid peroxidation and tyrosinase inhibition by lichen symbionts grown in vitro. Afr J Biochem Res. 2008; 2(12):225231.

2. Ahti, T. (2000). Flora Neotropica Monograph 78: Cladoniaceae. The New York Botanical Garden Press; Bronx, NY. pp. 1-362.

3. Mattsson JE, Wedin M. Phylogeny of the ParmeliaceaeDNA data versus morphological data. Lichenol. 1998; 30(4-5): 463-472

4. Boustie J, Tomasi S, Grube M. Bioactive lichen metabolites: alpine habitats as an untapped source. Phytochem Rev. 2011; 10(3): 287-307.

5. Molnar K, Farkas E. Current results on biological activities of lichen secondary metabolites: a review. Z Naturforsch. 2010; 659(3-4):157-173.

6. Ranković, B. \& Kosanić, M. (2019). Lichens as a potential source of bioactive secondary metabolites. In Lichen Secondary Metabolites, $1^{\text {st }}$ ed. Springer, Cham. pp. 1-29.

7. Kumar J, Dhar P, Tayade AB, Gupta D, Chaurasia OP, Upreti DK, Srivastava RB. Antioxidant capacities, phenolic profile and cytotoxic effects of saxicolous lichens from trans-Himalayan cold desert of Ladakh. PloS one. 2014; 9(6): e98696.

8. Ranković B, Kosanić M, Manojlović N, Rančić A, Stanojković T. Chemical composition of Hypogymnia physodes lichen and biological activities of some its major metabolites. Med Chem Res. 2014; 23(1): 408-416.

9. Hidalgo ME, Fernandez E, Quilhot W, Lissi E. Antioxidant activity of depsides and depsidones. Phytochemistry. 1994; 37(6): 1585-1587.

10. Shukla V, Joshi GP, Rawat MSM. Lichens as a potential natural source of bioactive compounds: a review. Phytochem Rev. 2010; 9(2): 303-314.

11. Tomović J, Kosanić M, Ristić S, Ranković B, Stanojković T, Manojlović N. Chemical composition and bioactive properties of the lichen, Pleurosticta acetabulum. Trop J Pharm Res. 2017; 16(12), 2977-2984.

12. Kosanić M, Ristić S, Stanojković T, Manojlović N, Ranković B. Extracts of five Cladonia lichens as sources of biologically active compounds. Farmacia. 2018; 6(4):644-651.

13. Dobson, F.S. (2011). Lichens: an illustrated guide to the British and Irish species. sixth ed. Richmond Publishing Co. London. 
14. Singleton VL, Orthofer R, Lamuela-Raventós RM. Analysis of total phenols and other oxidation substrates and antioxidants by means of folin-ciocalteu reagent. Method Enzymol. 1999; 299: 152-178.

15. Meda A, Lamien CE, Romito M, Millogo J, Nacoulma OG. Determination of the total phenolic, flavonoid and proline contents in Burkina Fasan honey, as well as their radical scavenging activity. Food Chem. 2005; 91(3): 571-577.

16. Prieto P, Pineda M, Aguilar M. Spectrophotometric quantitation of antioxidant capacity through the formation of a phosphomolybdenum complex: specific application to the determination of vitamin E. Anal Biochem. 1999; 269(2): 337-341.

17. Kumarasamy Y, Byres M, Cox PJ, Jaspars M, Nahar L, Sarker SD. Screening seeds of some Scottish plants for free radical scavenging activity. Phytother Res. 2007; 21(7): 615-621.

18. Smirnoff N, Cumbes QJ, Hydroxyl radical scavenging activity of compatible solutes. Phytochem. 1989; 28(4): 1057-1060.

19. Hinneburg I, Dorman HD, Hiltunen R. Antioxidant activities of extracts from selected culinary herbs and spices. Food chem.. 2006; 97(1): 122-129.

20. Oyaizu M. Studies on products of browning reaction. Jpn J Nutr. 1986; 44(6): 307-315.

21. Itharat A, Houghton PJ, Eno-Amooquaye E, Burke PJ, Sampson JH, Raman A. In vitro cytotoxic activity of Thai medicinal plants used traditionally to treat cancer. J Ethnopharmacol. 2004; 90(1): 33-38.

22. Sasidharan S, Chen Y, Saravanan D, Sundram KM, Latha LY. Extraction, isolation and characterization of bioactive compounds from plants' extracts. Afr J Tradit Complement Altern Med. 2011; 8(1):1-10

23. Socaci SA, Fărcaş AC, Diaconeasa ZM, Vodnar DC, Rusu B, Tofană M. Influence of the extraction solvent on phenolic content, antioxidant, antimicrobial and antimutagenic activities of brewers' spent grain. J Cereal Sci. 2018; 80:180-187.

24. Jha BN, Shrestha M, Pandey DP, Bhattarai T, Bhattarai HD, Paudel B. Investigation of antioxidant, antimicrobial and toxicity activities of lichens from high altitude regions of Nepal. BMC Complement Altern Med. 2017; 17(1): 282.

25. Behera BC, Verma N, Sonone A, Makhija U. Determination of antioxidative potential of lichen Usnea ghattensis in vitro. LWT Food Sci Technol. 2006; 39(1): 8085.

26. Tomovic J, Kosanic M, Rankovic B, Vasiljevic P, Najman S, Manojlovic N. Phytochemical analysis and biological activity of extracts of lichen Physcia semipinnata: as a new source of pharmacologically active compounds. Farmacia. 2019; 67(2): 346-353.

27. Aoussar N, Manzali R, Nattah I, Rhallabi N, Vasiljevic P, Bouksaim M, Mellouki F. Chemical composition and antioxidant activity of two lichens species (Pseudevernia furfuracea L and Evernia prunastri L) collected from Morocco. J Mater Environ Sci. 2017; 8(6): 1968-1976.
28. Pavithra GM, Vinayaka KS, Rakesh KN, Junaid S, Dileep N, TR PK, Naik AS. Antimicrobial and antioxidant activities of a macrolichen Usnea pictoides G. Awasthi (Parmeliaceae). J App Pharm Sci. 2013; 3(8): 154-160.

29. Ranković B, Kosanić M, Stanojković T, Vasiljević P, Manojlović N. Biological activities of Toninia candida and Usnea barbata together with their norstictic acid and usnic acid constituents. Int J Mol Sci. 2012; 13(11): 14707-14722.

30. Saha MR, Hasan SMR, Akter R, Hossain MM, Alam MS, Alam MA, Mazumder MEH. In vitro free radical scavenging activity of methanol extract of the leaves of Mimusops elengi Linn. Bangl J Vet Med. 2008; 6(2): 197-202.

31. Žilić S, Šukalović VHT, Dodig D, Maksimović V, Maksimović M, Basić Z. Antioxidant activity of small grain cereals caused by phenolics and lipid soluble antioxidants. J Cereal Sci. 2011; 54(3): 417-424.

32. Kosanić M, Manojlović N, Janković S, Stanojković T, Ranković B. Evernia prunastri and Pseudoevernia furfuraceae lichens and their major metabolites as antioxidant, antimicrobial and anticancer agents. Food Chem Toxicol. 2013; 53: 112-118.

33. Kosanić M, Ranković B, Stanojković T, Rančić A, Manojlović N. Cladonia lichens and their major metabolites as possible natural antioxidant, antimicrobial and anticancer agents. LWT Food Sci Technol. 2014; 59(1): 518-525.

34. Manojlović N, Ranković B, Kosanić M, Vasiljević P, Stanojković T. Chemical composition of three Parmelia lichens and antioxidant, antimicrobial and cytotoxic activities of some their major metabolites. Phytomedicine. 2012; 19(13): 1166-1172.

35. Odabasoglu F, Aslan A, Cakir A, Suleyman H, Karagoz Y, Bayir Y, Halici M. Antioxidant activity, reducing power and total phenolic content of some lichen species. Fitoterapia. 2005; 76(2): 216-219.

36. Zeytinoglu H, Incesu Z, Tuylu BA, Turk AO, Barutca B. Determination of genotoxic, antigenotoxic and cytotoxic potential of the extract from lichen Cetraria aculeata (Schreb.) Fr. in vitro. Phytother Res. 2008; 22(1): 118123.

37. Bézivin C, Tomasi S, Lohézic-Le Dévéhat F, Boustie J. Cytotoxic activity of some lichen extracts on murine and human cancer cell lines. Phytomedicine. 2003; 10(6-7): 499-503.

38. Muggia L. Lichens as treasure chests of natural products. Sim News. 2009; 59(3): 85-97.

39. Molnár K, Farkas E. Current results on biological activities of lichen secondary metabolites: a review. Z Naturforsch. 2010; 65(3-4): 157-173.

40. Brisdelli F, Perilli M, Sellitri D, Piovano M, Garbarino JA, Nicoletti M, Celenza G. Cytotoxic activity and antioxidant capacity of purified lichen metabolites: an in vitro study. Phytother Res. 2013; 27(3): 431-437.

41. Correche E, Carrasco M, Giannini F, Piovano M, Garbarino J, Enriz D. Cytotoxic screening activity of 
secondary lichen metabolites. Acta Farm Bonaerense. 2002; 21(4): 273-278.

42. Correché ER, Enriz RD, Piovano M, Garbarino J, Gómez-Lechón MJ. Cytotoxic and apoptotic effects on hepatocytes of secondary metabolites obtained from lichens. Altern Lab Anim. 2004; 32(6): 605-615.
43. Pejin B, Iodice C, Bogdanović G, Kojić V, Tešević V. Stictic acid inhibits cell growth of human colon adenocarcinoma HT-29 cells. Arab J Chem. 2017; 10(1): 1240-1242. 